\title{
Animacy, Anaphora and Language Change in Swedish
}

\author{
Dominika Skrzypek \\ dosk@amu.edu.pl \\ Adam Mickiewicz University, \\ Poznań, Poland
}

\begin{abstract}
This paper considers the role of animacy in the overt marking of indirect anaphors, i.e., noun phrases (NP), which introduce new discourse referents, that are grounded in the preceding discourse by means of a grounding element, an anchor. The indirect anaphors are considered in a diachronic perspective with reference to the emergent definite article and the variation between the article and other marking elements, in particular possessive pronouns. The study is based on an annotated corpus of Swedish prosaic texts from 1200-1550, which is a period of time when the definite article undergoes the process of grammaticalization in this language. The material was sorted according to the different combinations of the animacy of the anchor and the anaphor. The indirect anaphors which are anchored by means of expressions referring to animate entities show more variation of expression than those expressions referring to inanimate entities at the onset of definite article grammaticalization, but as the grammaticalization progresses, all indirect anaphors are by default expressed by the definite article. This is connected with the ongoing grammaticalization of the definite article and its extended use in new contexts.
\end{abstract}

Keywords: animacy; indirect anaphora; language change; definite article; Swedish

\section{INTRODUCTION}

This paper considers the role of animacy in the overt marking of indirect anaphors, i.e., noun phrases (NPs) which introduce new discourse referents grounded in the preceding discourse. The indirect anaphors are studied in a diachronic perspective with reference to the emergent definite article and the variation between the article and other marking elements, in particular possessive pronouns. It is argued here that the choice of the anaphoric NP type: definite NP, possessive NP or bare noun, is conditioned by the animacy of the anaphor itself as well as its anchor, i.e., the nominal which serves as a grounding element for the indirect anaphor. The study is based on an annotated corpus of Swedish texts from 1200-1550, which is a period when the definite article is formed in this language.

Definiteness in Modern Swedish is expressed by the definite article, which is a suffix always attached to the noun, etymologically a demonstrative pronoun hinn (Stroh-Wollin, 2016), e.g., sten-en 'the stone'. When the defNP includes adjectival modifiers these appear in the so-called weak form and with a preposed determiner, etymologically a demonstrative pronoun sá. Both the suffixed definite article and the preposed determiner can be combined within one NP (so-called double definiteness), e.g., den stora stenen 'the big stone'. The onset of the grammaticalization of the definite article in Swedish predates the extant sources (apart from the relatively short runic inscriptions) and was completed by the 16 th century.

The paper is organized as follows: first, the definition, typology, and previous research on indirect anaphora are presented, followed by the presentation of the methodology and the material used in this study. The results of the corpus study are reported with the material sorted according to the proposed methodology. The final section contains the conclusions and discussion of potential new research avenues in connection with indirect anaphora. 


\section{PREVIOUS RESEARCH ON INDIRECT ANAPHORA}

Indirect anaphora is a type of bridging reference, a relationship between two objects or events. It not spelled out and yet constitutes an essential part of the content of the text, as without this information the text would be rendered incoherent through the lack of connection between these objects or events (Asher \& Lascarides, 1998). The anaphoric element typically introduces a new discourse referent; yet it appears as definite NP (defNP, example (1)), though other NP types are possible as well, such as possessive NPs (poss NPs, example (2) or even indefinite NPs (indefNPs, example (3)).

(1) I've just read an interesting book. The author is Swedish.

(2) Jack locked himself out again. He had left his keys on the kitchen table.

(3) Jack was going to commit suicide. He got a rope.

(example (2) after Skrzypek, 2020: 174; example (3) after Asher \& Lascarides, 1998: 83)

The anchor is the element which grounds the anaphor in the discourse. It may be another nominal, a verbal element, a whole clause or even the text itself. In examples (1)-(3) above, the entities that can be considered anchors are an interesting book, locked himself out, and suicide.

Indirect anaphora is a heterogenuous context with many subtypes. So far, several classifications have been proposed, most notably Clark (1983), Cornish (1996), and Irmer (2011). In a study based on extensive material from modern German, Schwarz-Friesel (2007) proposes the following classification:

a. meronymic types, i.e., part-whole relations, e.g., a house-the roof;

b. lexical/thematic types, which are based on thematic roles such as instrument, object, agent, etc., e.g., to murder-a murderer;

c. scheme-based conceptual types, in which a more general knowledge of the world needs to be applied, e.g., a restaurant-the waiter;

d. inference-based conceptual types, where the correct interpretation of the anaphor and its relation with the anchor involved deduction; this type is usually found in the punchlines of jokes.

Schwarz-Friesel's classfication, as well as a number of other taxonomies of indirect anaphora, propose the classification of indirect anaphors based on the nature of the relationship between the anchor and the anaphor. Most studies are also limited to instances in which the anaphor is a defNP (Asher \& Lascarides (1998) being one of few exceptions), irrespective of the form of the anchor.

In the present paper, we would like to propose an alternative classification of indirect anaphors, which is based on the animacy of the anaphor and the anchor (the typology is thus limited to indirect anaphors with nominal anchors). Treating animacy as a binary opposition between +animate and -animate, the following combinations are possible, exemplified from Modern Swedish (the anaphors are given in bold and anchors are underlined).

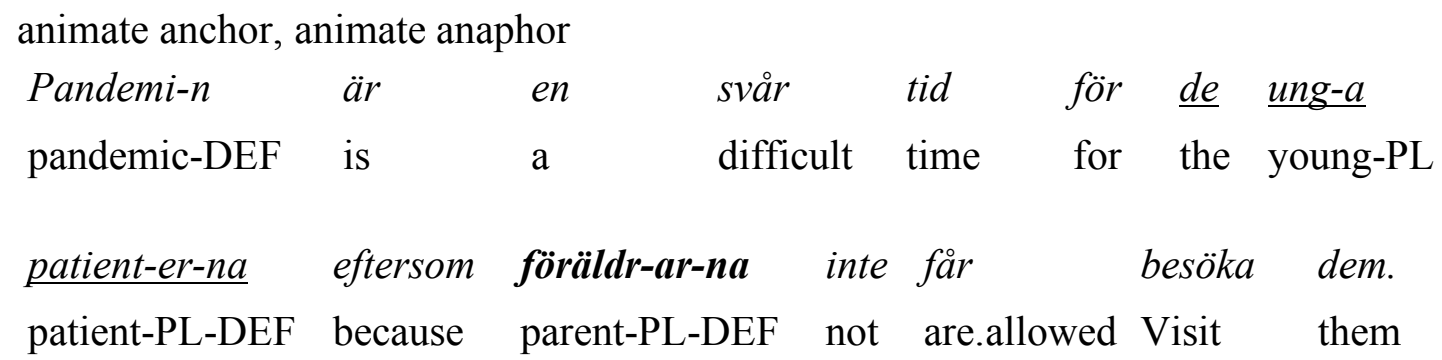


'The pandemic is a difficult time for the young patients because their parents are not allowed to visit them.'

animate anchor, inanimate anaphor

$\begin{array}{llllllll}\text { Hon } & \text { slog } & \text { till } & \underline{\text { honom }} & \text { så att } & \text { skall-en } & k n a ̈ c k-t e-s . \\ \text { she } & \text { hit } & \text { to } & \text { him } & \text { so that } & \text { skull-DEF } & \text { crack-PST.PASS }\end{array}$

'She hit him so that his skull cracked.'

(6) inanimate anchor, animate anaphor

\begin{tabular}{|c|c|c|c|c|c|c|}
\hline Jag & har & nyligen & läst & $\underline{e n}$ & intressant & artikel \\
\hline I & have & newly & read & $\mathrm{a}$ & interesting & article \\
\hline
\end{tabular}

$\begin{array}{lllll}\text { Afrika. } & \text { Författare- } \boldsymbol{n} & \text { komm-er } & \text { från } & \text { Togo. } \\ \text { Africa } & \text { author-DEF } & \text { come-PRES } & \text { from } & \text { Togo }\end{array}$

'I have just read an interesting article about Africa. The author comes from Togo.'

$$
\begin{aligned}
& \text { inanimate anchor, inanimate anaphor } \\
& \text { Vi fick bryta ner } \underline{\text { dörr-en }} \text { eftersom Johan tappa-de nyckel-n. } \\
& \text { we get-PST break down door-DEF because Johan lose-PST key-DEF }
\end{aligned}
$$

'We had to break down the door because Johan had lost the key.'

In all examples the form of the indirect anaphors appear as defNPs. This is the unmarked choice. It is possible to use possNPs in all examples but (6), so the indirect anaphor would be deras föräldrar 'their parents', hans skalle 'his skull', sin nyckel 'his key'1. The possNPs seem more emphatic, but a study on the interchangeability of the two NP types is called for to explain the conditions and limits of such variation.

Indirect anaphora is considered a so-called switch context (Heine, 2002) in the grammaticalization of the definite article, i.e., a context in which it is no longer possible to use a demonstrative determiner (from which the definite article develops). Thus, a form that is used in such a context, although it may be formally similar or identical to a demonstrative determiner, is considered to be a definite article (de Mulder and Carlier, 2011, Skrzypek, 2020). As indirect anaphora is a heterogenous context, it is likely that the incipient definite article first appears in one type of indirect anaphoric context and thence spreads to other types. So far, indirect anaphora has seldom been considered in a diachronic perspective. Skrzypek (2020) applies the Schwarz-Friesel typology of indirect anaphors to Old Danish and Old Swedish material and argues that the meronymic types are the last to show definite article marking, and are rather expressed by either possNPs or BNs even after all other indirect anaphors are uniformly defNPs. The present paper argues that the diachronic development may be better captured when indirect anaphors are sorted according to the animacy of the anchor and the anaphor.

1 The possessive $\sin$ is a reflexive variant used with all third person possessors. 


\section{METHODOLOGY AND DATA COLLECTION}

The study is diachronically oriented and based on an annotated corpus of Old Swedish texts from 1200-1550. Swedish is a North Germanic language, belonging to the eastern branch (Bandle et al., 2002). Extensive studies of definite article formation are available for the language (Skrzypek, 2012, Stroh-Wollin, 2015 and 2016) and there is a corpus of extant texts which can be utilized for the present study. The present corpus consists of texts representing three prosaic genres, namely, legal, religious, and profane prose, written between the year 1200 and 1550. The timeframe is further subdivided into three periods: period I (1200-1350), period II (1350-1450) and period III (1450-1550). The delimitations stem from major social events which affected the linguistic developments in the area, i.e., the introduction of the Latin script in early 13th century, the Black Death which decimated the Scandinavian population between 1348 and 1350, and the stabilization of the new social and linguistic order by 1450. By the year 1550 Sweden underwent other major social changes, which affected the languages, i.e., the break with the Catholic church and Reformation, the introduction of print, and the translation of the Bible into Swedish.

The corpus utilized for the present study was compiled from digitalized texts, available through the largest repository of Old Swedish texts: Fornsvenska textbanken ${ }^{2}$ (Old Swedish Textbank) by Lars-Olof Delsing. The number of tokens and the annotated NPs are presented in Table 1.

TABLE 1. Tokens and annotated NPs in the corpus

\begin{tabular}{ccc}
\hline Period & Tokens & Annotated NPs \\
\hline Period I (1200-1350) & 47,434 & 1,194 \\
Period II (1350-1450) & 27,700 & 1,093 \\
Period III (1450-1550) & 12,027 & 635 \\
Total & 87,161 & 2,922 \\
\hline
\end{tabular}

The texts were annotated using the manual tagging system DiaDef (Diachrony of Definiteness), based on the open-source Tagger framework. The system was tailor-made for the project of which the present study is a part. Its features include the import of texts in textual format into documents, the storing of metadata (e.g., language and period), the automatic splitting of the text into sentences and individual words (which can easily be overridden by the user), and the manual assignment of tags to individual words. A number of tags are predefined but their list can be extended to suit the individual needs of the project; the DiaDef tool is very flexible, as it enables non-restricted editing and adding of tags on different levels of annotation.

The system also provides several features that improve the efficiency of use, such as a context-sensitive list of prompts of available annotation tags. Furthermore, each annotation decision is saved automatically in a periodically backed-up database, which ensures protection against the loss of annotations. The system generates statistics concerning the occurrences of specific classes of words and word collocations - in a specified document or collection of documents.

NPs were annotated at seven levels: Lexeme (giving the English lexical equivalent), POS (part of speech), ART (article), REF (reference), Grammar (including information on case, gender and number of the head noun), Syntax (including information on the function of the NP, e.g., the subject), and Semantics (including information on animacy). The ART level indicated

2 Fornsvenska textbanken, https://project2.sol.lu.se/fornsvenska/ 
the type of modification of the head noun, utilizing the following tags: -IN (postposed definite article), DEN (preposed definite article), DEM (other determiners/demonstratives), BN (bare noun in the singular), BN-PL (bare noun in the plural), EN (indefinite article), POSS-PRO (possessive pronoun), POSS-REFL (possessive reflexive pronoun), and POSS-GEN (possessive genitive modifier). The REF level indicated the function of the NP in the discourse, utilizing the following tags: DIR-A (direct anaphora), INDIR-A (indirect anaphora), U (unique reference), G (generic reference), NEW (new referent), SPEC (specific reference), NON-SPEC (non-specific reference), NON-REF (non-referential).

For the purpose of the present study the annotation system was equipped with the Anchor feature. It enables the annotation of an element of the preceding discourse that serves as an anchor for the indirect anaphor. Thus, for each NP annotated as indirect anaphor, it was easy to access its anchor and to create a map of possible combinations and relations. The data obtained was sorted manually according to the feature animacy. Finally, a note on annotation of a diachronic corpus is due here. Diachronic corpora are notoriously difficult to annotate but even so, indirect anaphora is one of the more challenging annotation issues, as it is often not clear what the anchoring element is. In the present study, only the nominal anchors were taken into account, which made the annotation easier, even if not all annotation decisions were always straightforward. We have decided to define indirect anaphora as broadly as possible and we have included debatable cases in our annotation. Basically, if an NP included a noun which had a co-referring NP with an identical head noun in the preceding text, it was annotated as direct anaphor; if there was no identity between the head nouns, the NP was annotated as indirect anaphora. In literature, such cases are usually classified as (direct) anaphora, as the two NPs are co-referring. However, usually this is a case of so-called unfaithful anaphora (Lundquist, 2007), i.e., the two NPs are not unequivocally co-referring as the discourse referent is presented from a new perspective or with new information. This is illustrated by example (8).

\begin{tabular}{|c|c|c|c|c|c|c|c|c|c|}
\hline$\underline{\text { Han }}$ & gik & \multirow{2}{*}{$\begin{array}{l}\text { ena } \\
\text { one }\end{array}$} & \multirow{2}{*}{\multicolumn{2}{|c|}{$\begin{array}{l}\text { nat } \\
\text { night }\end{array}$}} & hoent & \multirow{2}{*}{\multicolumn{2}{|c|}{$\begin{array}{c}\text { saeng } \\
\text { bed }\end{array}$}} & ther & hon \\
\hline he & went & & & & her & & & where & she \\
\hline soff & $m z$ & \multicolumn{2}{|c|}{ barn-it } & $O c$ & myrdhe & \multicolumn{2}{|l|}{$\underline{\sin S}$} & \multicolumn{2}{|c|}{ brodher-s } \\
\hline slept & with & \multicolumn{2}{|c|}{ child-DEF } & and & murdered & \multicolumn{2}{|c|}{ his.REFL } & \multicolumn{2}{|c|}{ brother-GEN } \\
\hline barn & $o c$ & \multirow{2}{*}{\multicolumn{2}{|c|}{$\begin{array}{l}\text { hoenne } \\
\text { her }\end{array}$}} & \multirow{2}{*}{$\begin{array}{l}\text { sofwande } \\
\text { sleeping }\end{array}$} & stak & an & \multicolumn{2}{|c|}{ knifw-in } & $j$ \\
\hline child & and & & & & stuck & & knif & e-DEF & in \\
\hline hoenna & hand & & AEn & hon & waknadhe & aff & & thy & at \\
\hline her & hand & & and & she & woke & of & & this & that \\
\hline blodh-it & fløth & & vnder & hoenna & sidho & Hon & & byriadhe & ropa \\
\hline blood-DEF & flowe & & under & her & side & she & & started & scream \\
\hline swa & $a t$ & alt & & & waknadhe & $o c$ & & komo & thith \\
\hline $\mathrm{t}$ & that & all & & -DEF & woke & and & & came & there \\
\hline
\end{tabular}




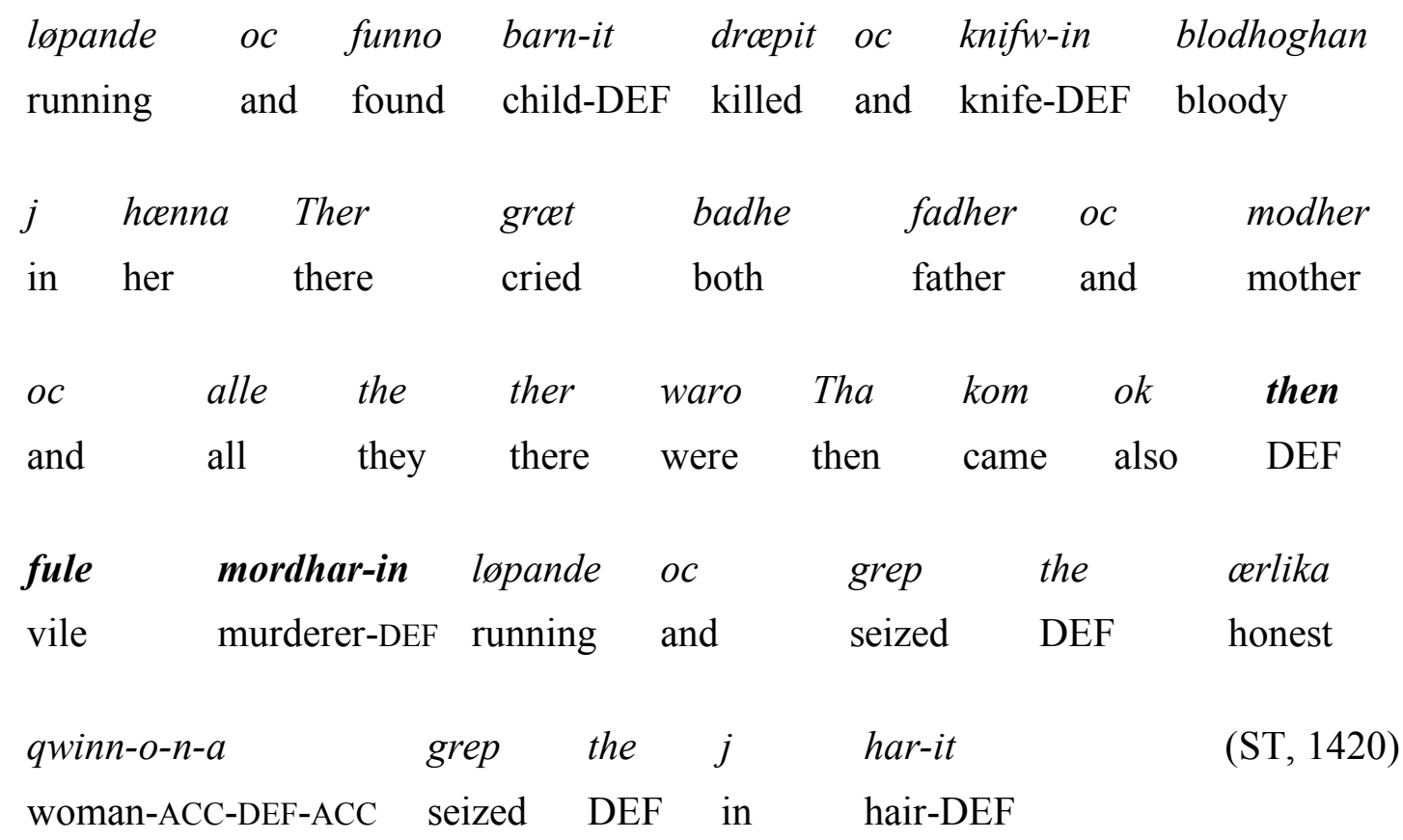

'One night he went to her bed, in which she slept with the child, and murdered his nephew and planted the knife in her hand. And she woke feeling blood flow under her side. She started to scream so that everybody woke and came running and found the child killed and the bloody knife in her hand. Mother, father and all people who were there cried. Also, the vile murderer came running and grabbed the honest woman by her hair.'

The young knight from the beginning of the story is a brother of the emperor who falls in love with one of the courtiers employed to mind the emperor's child. She did not reciprocate his feelings, so as a revenge he murdered the emperor's child in her care, leaving evidence pointing to her guilt. The first reference to the knight is with an indefNP en unger riddare ' $\mathrm{a}$ young knight'. After the murder is described (myrdhe 'murdered') he is referred to by means of a defNP then fule mordharin 'the vile murderer', with a different head noun. Although both NPs are co-referential ('the young knight' is identical with 'the vile murderer') the reader would not be able to link them without the intervening description of the murder. To avoid missing out on important data we have therefore treated unfaithful anaphors as indirect anaphors.

\section{RESULTS AND DISCUSSION}

We expect the percentage of indirect anaphors to be more or less constant across languages and periods. In the corpus we find that around $20 \%$ of annotated NPs are used as indirect anaphors. The detailed results are shown in Table 2.

TABLE 2. Indirect anaphors in Swedish across periods

\begin{tabular}{ccc}
\hline & Total number of NPs & $\begin{array}{c}\text { NPs used as indirect } \\
\text { anaphors }\end{array}$ \\
\hline Period I (1200-1350) & 1,194 & $24.37 \%$ \\
Period II (1350-1450) & 1,093 & $19.05 \%$ \\
Period III (1450-1550) & 635 & $20.47 \%$ \\
\hline
\end{tabular}

The data in Table 2 does not reveal the form of the anaphor - both defNPs and possNPs are found here as well as BNs. The proportions of all NP types are given in Table 3. Note that 
there is also a significant group of anaphors which belong to neither category and are presented under the heading 'other'. We find mainly NPs with adjectival modifiers here but no articles.

TABLE 3. The form of indirect anaphors in Swedish across periods

\begin{tabular}{cccccc}
\hline & BN & defNP & possNP & other & Sum \\
\hline $\begin{array}{c}\text { Period I } \\
(1200-1350)\end{array}$ & $40.55 \%$ & $8.93 \%$ & $35.74 \%$ & $14.78 \%$ & $100,00 \%$ \\
$\begin{array}{c}\text { Period II } \\
(1350-1450)\end{array}$ & $11.54 \%$ & $18.27 \%$ & $54.33 \%$ & $15.86 \%$ & $100,00 \%$ \\
$\begin{array}{c}\text { Period III } \\
(1450-1550)\end{array}$ & $13.08 \%$ & $10.77 \%$ & $60.77 \%$ & $15.38 \%$ & $100,00 \%$ \\
\hline
\end{tabular}

The results indicate that in Period I the indirect anaphors could be either BNs or possNPs (circa $40 \%$ for each NP type). As the grammaticalization of the definite article progresses, the BNs are only marginally allowed in the indirect anaphoric contexts; instead, the indirect anaphors are either possNPs or defNPs. As early as in Period II we see that circa $60 \%$ of the indirect anaphors are possNPs. At the same time, we see that the use of the defNPs does increase significatly, rather it is possNPs that appear with higher frequency. A possible explanation is that the relation between the anchor and the anaphor can be made more explicit by means of the possNP (in lieu of the defNP), and this possibility is utilized in the corpus.

The purpose of the present study is to inspect the indirect anaphors more closely, i.e., with respect to the different combinations of animate/inanimate anchor and animate/inanimate anaphor. Authentic examples of each type are given in (9)-(12) below. For each example, the reference to the source text is provided, stating the language ( $\mathrm{SW}=\mathrm{Swedish})$, text acronym (e.g., Jart=Järteckensboken, see Sources), and (approximate) the year of composition. In the examples, the anaphors are given in bold and anchors are underlined.

animate anchor, animate anaphor

$\begin{array}{lllllll}\text { Sitcer } & \text { konce } & i & \text { bo } & \text { dör } & \text { bonde } & (\ldots) . \\ \text { sits } & \text { wife } & \text { in } & \text { house } & \text { dies } & \text { husband } & \end{array}$

(AVL 1225)

'If a woman is in a household and her husband dies ...'

(10) animate anchor, inanimate anaphor

$\begin{array}{llllllll}\underline{\text { Kwinna-n}} & \text { gik } & \text { bort } & \text { ok faldadhe } & \text { han } & j & \text { sin-om } \\ \text { woman-DEF } & \text { went } & \text { away } & \text { and folded } & \text { him } & \text { in } & \text { her-DAT }\end{array}$

$\begin{array}{lllllll}\text { hwiff } & \text { som } & \text { hon haf-dhe } & \text { a sin-o } & \text { hofdh-e. } \\ \text { scarf } & \text { which } & \text { she have-PST } & \text { on her-DAT head-DAT }\end{array}$

'The woman went away and folded it [a sacramental wafer] into her scarf which she wore on her head.'

(11) inanimate anchor, animate anaphor

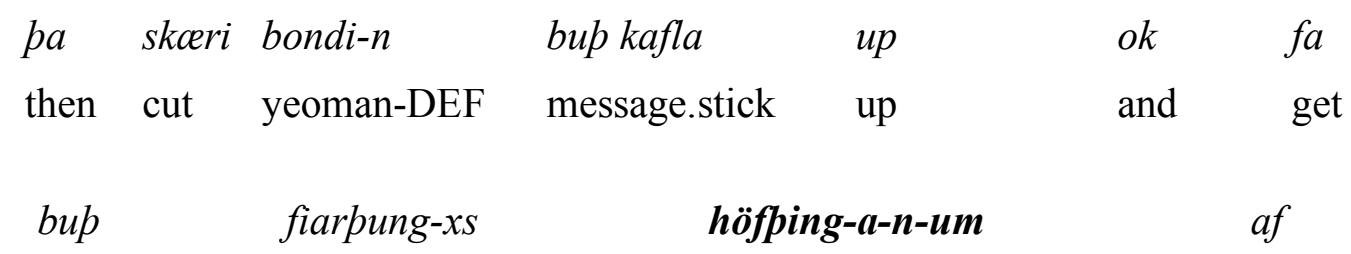




$$
\text { message fourth-GEN chief-OBL-DEF-DAT of }
$$

hoerap-i-n-u.

$(\mathrm{OgL}, 1280)$

hundred-DAT-DEF-DAT

'Then the yeoman shall carve a bidding stick (= a wooden stick with a message carved into it) and get the message to the chief of the quarter ${ }^{3}$ of the hundred (district).'

(12) inanimate anchor, inanimate anaphor

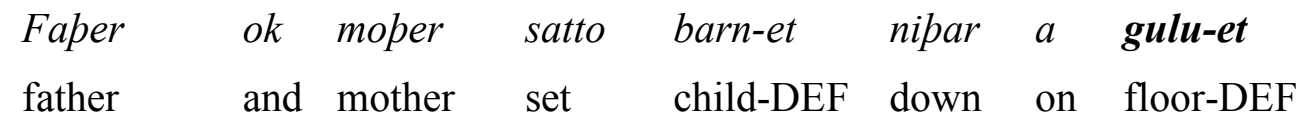

ii guz mønster.

(Bur, 1300)

in God.GEN temple

'Father and mother put the child on the floor in God's temple.'

A number of observations can be made based on the material at hand. Firstly, the form of the anaphor is by no means limited to defNPs. We find BNs in this context (example (9), as well as possNPs with a reflexive possessive (example (10). This is different from Modern Swedish, where the unmarked form of the indirect anaphor (in comparable contexts, i.e., with body part nouns) is defNP. Secondly, the different combinations of animacy of the anchor and the anaphor yield different semantic relations between the two constituents. Table 4 presents an overview of these types and their expressions in the Swedish material.

TABLE 4. Anchor-anaphor animacy.

\begin{tabular}{|c|c|c|c|c|c|c|}
\hline Anchor & Anaphor & $\begin{array}{c}\text { Examples } \\
\text { of semantic } \\
\text { relations }\end{array}$ & $\begin{array}{c}\text { NP type } \\
1200- \\
1350\end{array}$ & $\begin{array}{c}\text { NP type } \\
1350- \\
1450\end{array}$ & $\begin{array}{c}\text { NP type } \\
1450- \\
1550\end{array}$ & $\begin{array}{l}\text { NP type } \\
\text { Modern } \\
\text { Swedish }\end{array}$ \\
\hline tanimate & +animate & $\begin{array}{l}\text { Kinship } \\
\text { terms }\end{array}$ & $\mathrm{BN}$ & $\begin{array}{c}\mathrm{BN}, \\
\text { possNP }\end{array}$ & $\begin{array}{c}\mathrm{BN}, \\
\operatorname{defNP}, \\
\text { possNP }\end{array}$ & $\begin{array}{c}\mathrm{BN}, \operatorname{defNP}, \\
\text { possNP }\end{array}$ \\
\hline +animate & -animate & $\begin{array}{l}\text { Inalienable } \\
\text { possession }\end{array}$ & $\begin{array}{c}\text { BN, } \\
\text { defNP, } \\
\text { possNP }\end{array}$ & $\begin{array}{c}\text { possNP, } \\
\text { defNP }\end{array}$ & $\begin{array}{l}\text { possNP, } \\
\text { defNP }\end{array}$ & $\begin{array}{c}\text { possNP, } \\
\text { defNP }\end{array}$ \\
\hline -animate & tanimate & Ownership & $\mathrm{BN}$ & $\begin{array}{c}\mathrm{BN}, \\
\operatorname{defNP}\end{array}$ & defNP & $\operatorname{defNP}$ \\
\hline -animate & -animate & $\begin{array}{c}\text { Part-whole } \\
\text { relations }\end{array}$ & $\mathrm{BN}$ & $\begin{array}{c}\text { BN, } \\
\text { defNP }\end{array}$ & defNP & $\operatorname{defNP}$ \\
\hline
\end{tabular}

Different combinations of animacy of the anchor and the anaphor coincide with different types of semantic relations. The first group, where both the anchor and the anaphor are animate, is represented in the corpus by kinship terms in high proportion. In Period I the anaphor is a BN, gradually possNPs can also be used here (Period II), as well as defNPs (Period III). Interestingly, all three NP types can be used with kinship terms in Modern Swedish. Other semantic relations found here, e.g., priest-bishop, are expressed by BNs in Period I but by defNPs in Periods II and III, as well as in Modern Swedish (Koptjevskaja-Tamm, 2001). Example (13) shows a common kinship noun from Period I.

3 At this point in time it is not possible to definitely state whether this is a phrase or a compound. Since the elements are spelled separately, it was glossed and translated as a phrase. 


$$
\begin{array}{llll}
\text { Mopir } & \text { takar } & \text { syn-a } & \text { arf } \\
\text { mother } & \text { takes } & \text { son-GEN } & \text { inheritance }
\end{array}
$$

'Mother inherits after her son.'

The second group, with animate anchor and inanimate anaphor, is in the material represented mainly by relations of inalienable possession, i.e., the anchor is an animate being, the anaphor a body part, an item of clothing or a weapon worn. The unmarked marking of this relation in Modern Swedish is the defNP, but in the Old Swedish material we find only BNs or possNPs in Period I. In Period II the inalienables start appearing as defNPs, at first in anaphoric chains (a sequence of references to the same referent across the text). When the body part or other inalienable referent is referred to for the first time, it is done by means of a possNP; when it is the subsequent mention, it appears as a defNP. This is illustrated by example (14) below.

$\begin{array}{llllllll}\text { ok } & \text { quinna-n } & \text { lypte } & y p & \text { sina } & \text { hand } & \text { ok } & \text { strök } \\ \text { and } & \text { woman-DEF } & \text { lifted } & \text { up } & \text { her } & \text { hand } & \text { and } & \text { stroked }\end{array}$

$\begin{array}{llllllll}\text { sik } v m \text { änliti-t } & \text { ok tha hon tok nidhir hand-in-a } \\ \text { herself about face-DEF } & \text { and when she took down hand-ACC-DEF }\end{array}$

$\begin{array}{lll}\text { tha war hon } & \text { al blodogh } \\ \text { herself about face-DEF and when }\end{array}$

(Jart, 1385)

'And the woman lifted her hand and stroked her face and when she took the hand away it was all bloodied.'

However, in some texts from Period II we find that even the first mention of an inalienable referent is made by means of a defNP, which is a pattern familiar from Modern Swedish.

$\begin{array}{llllll}\text { Tha bar keysarin } & v p & \text { hand-ena } & \text { oc } & \text { slogh } \\ \text { then bore emperor-DEF up hand-DEF oc } & \text { hit }\end{array}$

'Then the emperor lifted his hand and hit her on her cheekbone so that she fell down.'

It should be noted here that even though the unmarked expression of inalienables in Modern Swedish is defNPs, it is possible to use possNPs here, especially if some emphasis is intended.

Other examples of semantic relations with animate anchor and inanimate anaphor include products or results of an action carried out by the agent, as in example (16) below, in which the inanimate indirect anaphor 'the killing' is anchored in the text by the animate 'the killer'. 


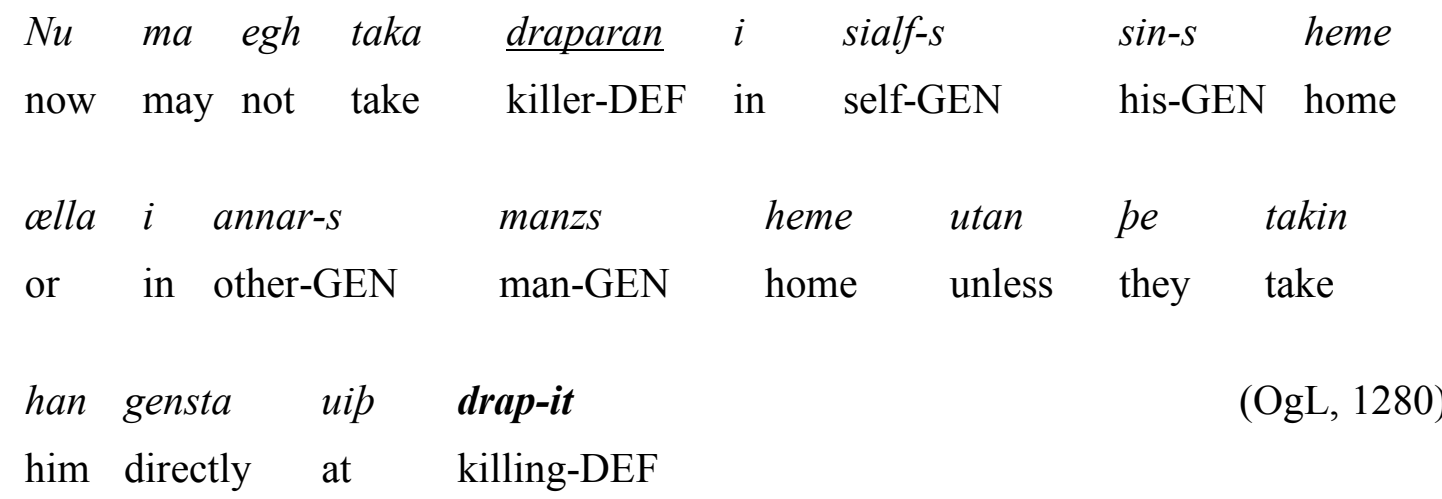

'The killer cannot be taken from his or somebody else's home unless he is caught red-handed.'

The third group consists of animate indirect anaphors which are grounded by means of inanimate anchors. This is a sparsely represented group in the material, but some examples could be found, in which the semantic relations could be defined as ownership, of the type $a$ house - the owner, authorship or producer, e.g., a book - the author, or an agent, e.g., an event - the participant. The few examples that were found showed definite marking as early as in Period I, as illustrated by example (17).

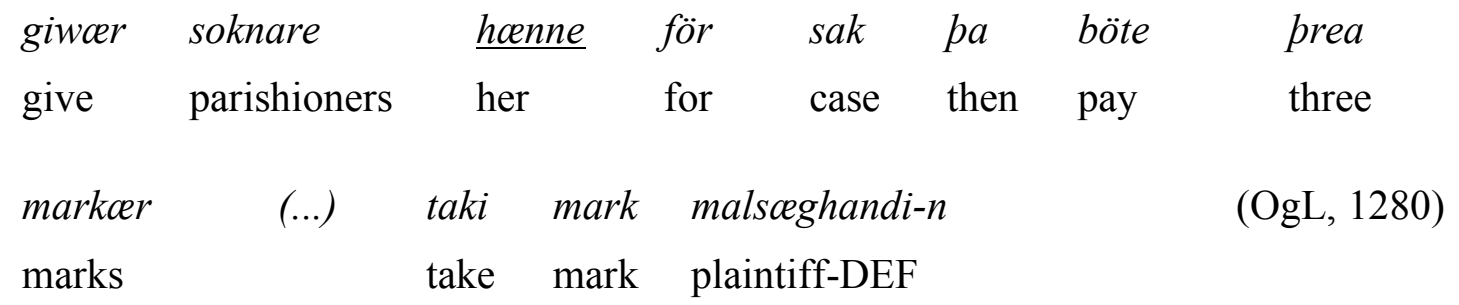

'If the parishioners accuse her, then should pay three marks (...) The plaintiff takes one mark.'

The last group consists of inanimate anaphors grounded in the discourse by inanimate anchors. Here a number of examples could be found, representing what is often considered a typical example of indirect anaphora, i.e., part-whole relations, e.g., a house - the roof. This group is quite similar to the previouse one, i.e., the anaphors appear as BNs in Period I and to some extent in Period II, but defNPs become the default marking in Period III and remain so in Modern Swedish. Examples (18) and (19) illustrate the use of either BNs or defNPs in Period I (both examples come from the same text).

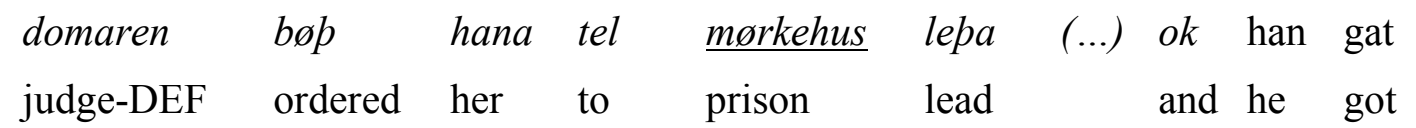

$\begin{array}{lllllll}\text { eigh } & \text { lasen } & \text { uplcest ok } & \text { eigh } & \text { dor } & \text { brutit } & \text { (Bur, 1300) } \\ \text { not } & \text { lock-DEF } & \text { unlocked and } & \text { not } & \text { door } & \text { broken } & \end{array}$

'The judge ordered that she be taken to the prison (...) and he failed to open the lock or break the door ...'

$\begin{array}{llllllll}\text { ba } & \text { vaxte } & \text { vaenast } & \underline{\text { lilia }} & \text { up } & \text { af } & \text { hans } & \text { graf } \\ \text { then } & \text { grew } & \text { most.beautiful } & \text { lily } & \text { up } & \text { of } & \text { his } & \text { grave }\end{array}$

Maen grouo tel rot-e-n-na

(Bur, 1300) 
men dug to root-DEF-GEN-DEF

'Then a most beautiful lily grew up from his grave (...) People dug to its root (...).'

Examples (20) and (21) come from Period II and Period III respectively and show the use of the defNP in indirect anaphoric context (part-whole relations).

$\begin{array}{llllllll}\text { Tha } & \text { gik } & \text { hon } & \text { in } & i & \text { hwsith } & \text { oc } & \text { stängde ater } \\ \text { then went } & \text { she } & \text { in } & \text { in house-DEF } & \text { and } & \text { closed } & \text { again }\end{array}$

$\begin{array}{lllll}\text { dörna } & o c & \text { gik } & \text { til } & \text { windöghath } \\ \text { door-DEF } & \text { and } & \text { went } & \text { to } & \text { window-DEF }\end{array}$

(SVM, 1420)

'Then she went into the house, closed the door and went to the window.'

$\begin{array}{lllllll}\text { Take kesaren } & i & \text { morghen } & \underline{\text { all }} & \underline{\text { the }} & \underline{\text { swärdh }} & \underline{\text { som }} \\ \text { take emperor-DEF } & \text { in } & \text { morning } & \text { all } & \text { DEF } & \text { word.PL which }\end{array}$

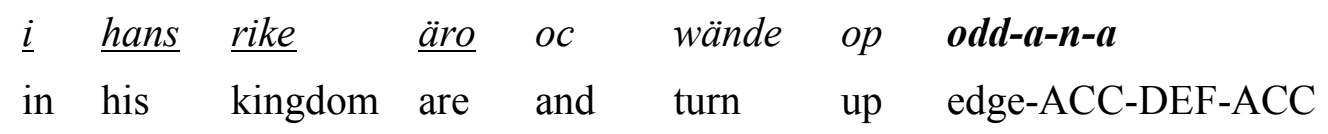

alla a them.

$(\mathrm{KM}, 1480)$

all on them

'Let the emperor next morning take all the swords which are in his kingdom and turn the edges upwards on each of them.'

The material discussed above suggests that there is a difference in the expression of the indirect anaphora depending on the animacy of the anchor. With inanimate anchors the development proceeds as much as we would expect it to, i.e., the indirect anaphors appear as BNs in Period I (at which time the definite article in the early stages of grammaticalization). However, in Period II, many defNPs can be found in this type of indirect anaphora and the defNP is the standard expression of the indirect anaphora in Period III (as it is in Modern Swedish).

When the anchor is animate, however, we observe a greater variation in the expressions of indirect anaphors. Fistly, the inalienable possession (animate anchor, inanimate anaphor) is in Period I and much of Period II expressed by possNPs rather than defNPs, which is the unmarked form of this type of indirect anaphor in Modern Swedish. Secondly, the kinship terms are expressed by BNs even long after the definite article is fully grammaticalized.

What we see, then, is that with animate anchor, different forms of the indirect anaphor are possible, which correlate with different semantic relations between the anchor and anaphor. With inanimate anchor, there is little variation across the periods studied, and irrespective of the animacy of the indirect anaphor it is always presented as a defNP in Modern Swedish.

The observation that the animacy of the anchor has a bearing on the expression of the indirect anaphora, also if considered diachronically, is, at this point, empirical only. Animacy splits occur frequently across languages and may influence all levels of linguistic expression (e.g., Bayanati \& Toivonen, 2019). The correlation between animacy and definiteness is also a well-studied phenomenon. But in this particular instance of indirect anaphora and its anchor, is there any cognitive mechanism which could be evoked to underpin this empirical observation? 
In the preceding sections we have used the term anchor to refer to the entity which grounds the indirect anaphor in the discourse and makes its resolution possible. In literature, another term is sometimes used with respect to this entity, namely trigger (Hawkins, 1978). One could argue that the two terms differ in perspective. Trigger seems to imply that on hearing it, a number of stereotypically connected entities will be activated in the hearer's mind, so preparing him or her for the appearance of indirect anaphors, which may then be presented as defNPs, even though they, strictly speaking, introduce new discourse referents. For example, the indefNP trigger a theater opens up a new reference frame, within which we find such potential discourse referents such as director, actor, stage, curtain, public, etc. If these are presented as defNPs, the hearer will automatically associate them with the trigger a theater and interpret them as being part of the said theater. The new reference frame (or reference domain, see Schwarz (2000) and her discussion of Referenzdomäne) allows presentation of new discourse referents as if they were familiar. From a cognitive perspective, triggers are instances of priming, i.e., a phenomenon of pre-activation, whereby the previous use of a certain linguistic element will affect (facilitate) the subsequent use of the same or similar linguistic element. The concept of priming is not limited to linguistics; within the field, it has mainly been used in psycholinguistic research. It has also occasionally been applied to diachronic data, as a means to account for the unidirectionality of language change in grammaticalization studies (Rosenbach, 2008).

The empirical data tells us so far that depending on the animacy of the trigger (anchor) there will be greater of lesser variation in the expression of the indirect anaphor. This variation reflects the fact that in combination with an animate trigger, there are a number of possible semantic relations, some of which require different realizations, whereas in combination with an inanimate trigger, the variation is more limited. In other words, animate triggers seem to open up more complex reference domains than inanimate ones.

Why should it be so? Admittedly, there are some semantic relations which are only possible with animate anchors (e.g., legal ownership, kinship); nevertheless, the majority of semantic relations are shared by animate and inanimate anchors, e.g., being part of something. Why do animate anchors induce varied anaphors while inanimate anchors do not?

It seems that in the history of Swedish, when the definite article grammaticalizes, at first, it omits contexts which can be realized by means of the reflexive possessive pronouns. However, as illustrated by example (14), when the referent is used again (i.e., it can be retrieved both via the anchor and the previous mention), it appears as defNP. This is different from English, where further mentions of body part nouns still appear as possNPs. We observe that the variation is highest in Period II, when the definite article enters its final stage of grammaticalization (Skrzypek et al., 2021). It seems that the choice of the NP type is to begin with conditioned by the animacy of the anchor, but gradually, as the grammaticalization of the definite article progresses, this variation is limited and all indirect anaphors are by default expressed by the definite article, apart from kinship terms.It seems that this is the crucial turning point in the history of the marking and one that results in the modern system, where the inalienables are presented as defNPs in unmarked contexts.

Another, potentially promising line of research may connect the animacy of the anchor with human memory and processing of animate vs. inanimate discourse referents. There are a number of studies (not linguistically-oriented) which report that people remember animate targets better than inanimate ones and the animacy of the item is the best predictor of its later recall (Nairne et al., 2017). In this research the animacy opposition studied is one between entities capable of independent movement (thus grouping humans and other animals together) and those that are not (inanimate objects including plants). Children show ability to distinguish between animate and inanimate entities from an early age (Markson \& Spelke, 2006), and animacy has been shown to facilitate learning; new facts about animate entities are learned 
quicker than those about inanimate ones (Barrett \& Broesch, 2012). One conclusion of the growing psychological research that seems of most benefit for the present study is that" animate items, on average, possess richer attributes or features" (Nairne et al., 2017 p. 26). This richness of attributes may find its linguistic expression in a greater variation of form of the indirect anaphor with animate triggers and relative lack of variation of form with inanimate ones. However, this tentative hypothesis requires a significant amount of research.

\section{CONCLUSIONS}

In the present paper we have considered indirect anaphoric relations and expressions of indirect anaphora in a diachronic corpus. The material was sorted according to the different combinations of the animacy of the anchor and the anaphor. We find that the indirect anaphors which are anchored by means of expressions referring to animate entities show more variation of expression, while the indirect anaphors anchored by means of expressions referring to inanimate entities do not show similar variation. In particular, the use of the possNPs with indirect anaphors anchored by inanimates was not found in the present material. This observation holds for the historical corpus, from the time of the definite article grammaticalization. As the definite article becomes fully grammaticalized, all indirect anaphors are by default expressed by the definite article.

The findings are not only of value for language change studies, but open a new avenue of cognitively-oriented studies on animacy. Based on recent psychological studies into correspondence between animacy and memory we argue that animate anchors (or triggers) open up wider refence domains than the inanimate ones, which is evidenced by the variability of the indirect anaphoric expressions.

\section{ACKNOWLEDGEMENTS}

Research presented in this paper was supported by the National Science Centre (NCN), Poland, research grant 2015/19/B/HS2/00143. The author gratefully acknowledges this support.

\section{SOURCES}

AVL $=$ Äldre Västgötalagen. In H. S. Collin, \& C. J. Schlyter (Eds.). (1827). Samling af Sweriges gamla lagar (Vol. 1). Stockholm: Haeggström. Manuscript Holm B 59.

Bur $=$ Codex Bureanus. In G. Stephens (Ed.). (1847). Ett fornsvenskt legendarium. Stockholm: Norstedt. Manuscript Holm A 34.

Did = Sagan om Didrik af Bern. G. O. Hyltén-Cavallius (Ed.). (1850-54). Stockholm: Norstedt. Manuscript Skokloster 115, 116 HAND A.

DL = Dalalagen. In H. S. Collin, \& C. J. Schlyter (Eds.). (1827). Samling af Sweriges gamla lagar (Vol. 5). Stockholm: Haeggström. Manuscript Holm B 54.

$\mathrm{HML}=$ Helga manna lefverne. In G. E. Klemming (Ed.). (1877-78). Klosterläsning. Stockholm: Norstedt. Manuscript Holm A 110 (Codex Oxenstierna).

Jart $=$ Järteckensboken. In G. E. Klemming (Ed.). (1877-78). Klosterläsning. Stockholm: Norstedt. Manuscript Holm A 110 (Codex Oxenstiernianus).

$\mathrm{KM}=$ Karl Magnus. In G. E. Klemming (Ed.). (1887-89). Prosadikter från Sveriges medeltid. Stockholm: Norstedt. Manuscript Holm D 4.

Kris = Kristoffers Landslag. In C. J. Schlyter (Ed.). (1869). Samling Af Sweriges Gamla Lagar (Vol. 12). Lund. Manuscript Holm B 23a.

Linc $=$ Linköpingslegendariet, Legenden om Sankt Amalberga. In G. Stephens (Ed.). (1847). Ett fornsvenskt legendarium. Stockholm: Norstedt. Manuscript Linc B 70a. 
OgL = Östgötalagen. In H. S. Collin, \& C. J. Schlyter (Eds.). (1827). Samling af Sweriges gamla lagar (Vol. 2). Stockholm: Haeggström. Manuscript Holm B 50.

Pent $=$ Pentateukparafrasen. Olof Thorell (Ed.). (1955). Fem Möseböcker på fornsvenska . Uppsala: Almqvist \& Wiksell. Manuscript Codex Thott (Köpenhamn).

$\mathrm{SVM}=$ Sju vise mästare. In G. E. Klemming (Ed.). (1887-89). Prosadikter från Sveriges medeltid. Stockholm: Norstedt. Manuscript Holm D 4.

$\mathrm{ST}=$ Själens tröst: Tio Guds bud förklarade genom legender, berättelser och exempel. G. E. Klemming (Ed.). (1873). Stockholm: Norstedt. Manuscript Holm A 108.

Troja = Historia Trojana. R. Geete (Ed.). (1892). Stockholm: Norstedt. Manuscript Holm D $3 \mathrm{a}$.

YVL = Yngre Västgötalagen. In H. S. Collin, \& C. J. Schlyter (Eds.). (1827). Samling af Sweriges gamla lagar (Vol. 1). Stockholm: Haeggström. Manuscript Holm B 58.

\section{REFERENCES}

Asher, N., \& Lascarides, A. (1998). Bridging. Journal of Semantics. Vol. 15(1), 83-113. https://doi.org/10.1093/jos/15.1.83

Bandle, O., Braunmüller, K., Jahr, E. H., Karker, A., Naumann, H.-P., Teleman, U., Elmevik, L., \& Widmark, G. (2002). The Nordic Languages. An International Handbook of the History of the North Germanic Languages. De Gruyter Mouton.

Barrett, H. C. \& Broesch, J. (2012). Prepared social learning about dangerous animals in children. Evolution \& Human Behavior, Vol. 33, 499-508. https://doi.org/10.1016/j.evolhumbehav.2012.01.003.

Bayanati, S. \& Toivonen, I. (2019). Humans, Animals, Things and Animacy. Open Linguistics, Vol. 5(1), 156-170. https://doi.org/10.1515/opli-2019-0010

Clark, H. H. (1983). Bridging. In P. N. Johnson-Laird \& P. C. Wason (Eds.), Thinking: Readings in Cognitive Science (pp. 311-326). Cambridge University Press.

Cornish, F. (1996). 'Antecedentless' Anaphors: Deixis, Anaphora, or What? Some Evidence from English and French. Journal of Linguistics, Vol. 32(1), 19-41.

De Mulder, W., \& Carlier, A. (2011). The grammaticalization of definite articles. In B. Heine \& H. Narrog (Eds.), The Oxford Handbook of Grammaticalization (pp. 522-535). Oxford University Press. https://doi.org/10.1093/oxfordhb/9780199586783.013.0042

Hawkins, J. (1978). Definiteness and indefiniteness: A study in reference and grammaticality prediction. London: Croom Helm.

Heine, B. (2002). On the role of context in grammaticalization. In I. Wischer \& G. Diewald (Eds.), New Reflections on Grammaticalizations (pp. 83-101). John Benjamins Publishing Company.

Irmer, M. (2011). Bridging Inferences. Constraining and Resolving Underspecification in Discourse Interpretation. Berlin: De Gruyter Mouton.

Koptjevskaja-Tamm, M. (2001). Kinship in grammar. In I. Baron \& M. Herslund \& F. Sørensen, (Eds.), Dimensions of possession (pp. 201-225). Philadelphia, Pa.: John Benjamins Publishing Company.

Lundquist, L. (2007). Lexical anaphors in Danish and French. In M. Schwarz-Friesel, M. Consten \& M. Knees (Eds.), Anaphors in Text. Cognitive, formal and applied approaches to anaphoric reference (pp. 37-48). John Benjamins Pub. Co.

Markson, L. \& Spelke, E. S. (2006). Infants' rapid learning about self-propelled objects. Infancy, Vol. 9, 45-71. https://doi.org/10.1207/s15327078in0901_3

Nairne, J.S., VanArsdall, J.E. \& Cogdill, M. (2017). Remembering the living: episodic memory is tuned to animacy. Current Directions in Psychological Science, Vol. 26, 22-27. 
Rosenbach, A. (2008). Language change as evolution - evolutionary approaches to language change. In R. Eckhardt, G. Jäger \& T. Veenstra, (Eds.), Variation, selection, development: probing the evolutionary model of language change (pp. 23-74). Berlin: Mouton de Gruyter.

Schwarz-Friesel, M. (2007). Indirect anaphora in text: A cognitive account. In M. SchwarzFriesel, M. Consten, \& M. Knees (Eds.), Anaphors in Text. Cognitive, formal and applied approaches to anaphoric reference (pp. 3-20). Amsterdam: John Benjamins.

Schwarz, M. (2000). Indirekte Anaphern in Texten: Studien zur domänengebundenen Referenz und Kohärenz im Deutschen. Tübingen: Niemeyer.

Skrzypek, D. (2012). Grammaticalization of (in)definiteness in Swedish. Poznań: Wydawnictwo Naukowe Uniwersytetu im. Adama Mickiewicza.

Skrzypek, D. (2020). Indirect anaphora in a diachronic perspective. The case of Danish and Swedish. In R. Van Valin \& K. Balogh (Eds.), Nominal Anchoring. Berlin: Language Sciences, 171-193.

Skrzypek, D., Piotrowska, A. \& Jaworski, R. (2021). The diachrony of definiteness in North Germanic. Leiden: Brill.

Stroh-Wollin, U. (2015). Från gammal man till den gamle mannen: Definitmarkering i fornsvenska nominalfraser med adjektivattribut. Arkiv För Nordisk Filologi, Vol. 130, 101-138.

Stroh-Wollin, U. (2016). The emergence of definiteness marking in Scandinavian - new answers to old questions. Arkiv För Nordisk Filologi, Vol. 131, 129-169.

\section{ABOUT THE AUTHOR}

Dominika Skrzypek is a professor of Scandinavian linguistics at the Institute of Scandinavian studies, Adam Mickiewicz University, Poznań, Poland. Her research interests include historical linguistics and runology. 